\title{
Turn Based Strategy Games to Hone Your Knowledge of Indonesian Culture Based on Android
}

\author{
$1^{\text {st }}$ F S Sulaeman \\ Suryakancana University. \\ Indonesia \\ Jl. KH. Saleh Gg. Rd. H. Affandi II \\ No. 66 Cianjur $43213^{1}$, Jl. Aria \\ Wiratanudatar Kavling Satria No. 15 \\ Kap. Warung Manggah, Kec \\ Karangtengan Kab Cianjur. ${ }^{2}$ \\ *fietrisetiawati@gmail.com
}

\author{
$2^{\text {nd }} \mathrm{D}$ P Aji \\ Department Midwifery \\ Suryakancana University. \\ Indonesia \\ Jl. KH. Saleh Gg. Rd. H. Affandi II \\ No. 66 Cianjur $43213^{1}$, Jl. Aria \\ Wiratanudatar Kavling Satria No. 15 \\ Kap. Warung Manggah, Kec \\ Karangtengan Kab Cianjur. ${ }^{2}$
}

\begin{abstract}
Games is a kind of entertainment that is liked by all people in all ages, both children and adults. Besides being used for entertainment, a game can also serve to train the mindset of someone in search of a solution to solve the existing problems on a game. The function of the game was created for the entertainment community that can be used by various people. However, in addition the game entertainment can be an education for the user. In this study, the authors make a game with a purpose other than for entertainment can also be useful in increasing knowledge, especially the knowledge of Indonesian culture. With this game expected to increase knowledge of the lovers of the game is to know the cultures that exist in Indonesia. The concept of the game is turn-based strategy is a two-dimensional games based on Android. Core of this game is must choose the correct answer from the problems that exist with the specified time in each warriors. Problem of the game is made up of traditional houses, traditional weapons, traditional dances, folk songs, and cultural heritage that exist in Indonesia.
\end{abstract}

Keywords-Turn Based Strategy, Games, Hone, Culture

\section{INTRODUCTION}

Game is a kind of entertainment that is liked by all people, in all ages, both children and adults. Besides being used for entertainment games can also be used to train the brain or train one's mindset in the search for a solution to solve the existing problems in a game. In the 2000s era technology has developed very rapidly. Almost all the fields are already using the technology, and one use of technology is the field of the game industry. Digital game industry, or better known as the gaming industry continues to follow the development of this technology. This is demonstrated by the many devices to play games that keep popping up and growing, such as mobile phone, tablet, PC, consoles (Playstation, Xbox and Nintendo Wii).
The function of the game was created for the entertainment community that can be used by various groups, in addition to entertainment games can also be an education for their user. Where in the gameplay gamers will get a knowledge, in addition to derive pleasure or amusement.

Making this game in addition to entertainment can also be useful to hone the ability of Indonesian culture knowledge. Thus, the image play games originally much negative impact, with the game will change the image to something more positive, because of the benefits that can be felt by gamers is more to hone knowledge, especially the knowledge of the cultures that exist in Indonesia.

\section{LITERATURE REVIEW}

There are some studies relating to the development stategy game is turn based, among others: Semiawan proposed game is a variety of activities that are actually designed with the intention that the child can increase some certain abilities based on experiential learning. [1]

Game presented by Lestari (in Pratama) within the meaning of Indonesian is a game. The game is a complex activity in which there are rules, play and culture.[2]

Culture literally comes from the Latin language that has meaning Colere work, land, cultivate, nurture and lading (according Soerjanto Poespowardojo). In addition the culture or cultures derived from Sanskrit that buddhayah, which is the plural of budhi (mind or intellect) is defined as matters related to the mind and human reason. [3]

game strategy in the study of Sanjaya, Budhi, and Liliana proposed strategy video game is a video game genre that emphasizes thinking and good planning to achieve victory. Players must carry out a series of actions against one or more enemies and trying to weaken your opponent 
as efficiently and quickly as possible [4]. Most of the game involves an element of war strategy and priority consideration a combination of tactics and strategy. This kind of game is often also challenge the ability of players to explore and regulate the economy.

In a strategy game, the main goal of the game session is beating all other players and be a winner.

\section{A. Genre Game Strategy}

Strategy games generally divided into two (2) subgenre, which is a turn based strategy and real time strategy.

\section{Turn Based Strategy}

In turn-based strategy players only run the action on the turn or turn away. Action can be taken generally be restricted, for example, a player can only do two (2) Any action in turn. Turn based strategy give freedom to the players to think without a limited time.

\section{Real Time Strategy}

In real time strategy, game run without a turn. All the action that the players in the game will have a direct impact on the course of the game. This subgenre encourage players to think fast and concentrate on the game.

\section{A. Educational Game}

According Handriyantini, educational game is a game designed and created to stimulate thought including improved concentration and problem solving.[5]

\section{RESEARCH METHOD}

The method used is MDLC (Multimedia Development Life Cycle), this method is a method of multimedia development that comes from Luther and reapplied by Sutopo which consists of six stages consisting of concept, design, material collecting, assembly, testing, and distribution. Sutopo (in Binanto 2010) adopted the methodology of Luther with modifications as shown in Figure 1.[6]

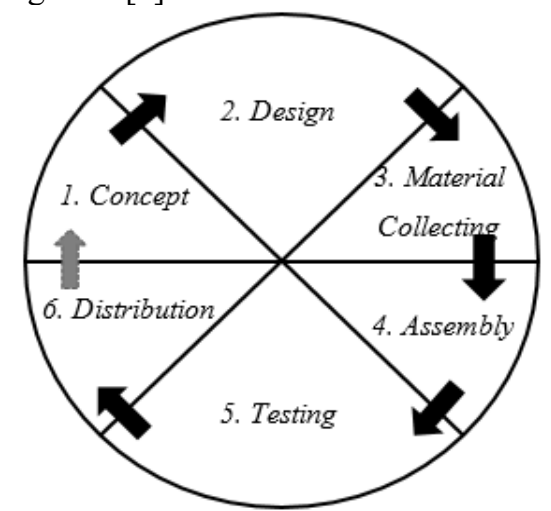

Fig. 1. Stages Multimedia Development (MDLC) [6]

\section{CONCEPT AND DESIGN}

The concept of games designed a two-dimensional games based on Android that contains the core concept of this game is a must choose the correct answer from the problems that exist within 10 seconds of each question are provided in this game. Problems in this game consists of questions of Indonesian culture, namely custom house, traditional weapons, folk songs, and cultural heritage of Indonesia.

In this study, the game was made to provide information on several cultures in Indonesia such as traditional houses, traditional weapons, traditional dances, folk songs, and cultural heritage. This game can also be easily used for which there are guides to playing the game.

\section{A. Game Design}

The design required in the making of this game is a game character design, gameplay, level, and the problems that exist in this game[7], In this game there are two characters, two game play that is VS computer and Multiplayer.

Level contained in this game there are 3 levels with 3 different difficulty levels, namely, easy, medium, and hard. To design problem consists of five types of grouping that is, a matter of custom homes, traditional weapons, traditional dance, traditional weapons, and historic relics.

\section{B. Use Case Diagram}

Use case is an abstraction of interaction between system and actor[8], There is 1 (one) actor and 9 (nine) use case in the making of this game. Between actors and use cases interact with each other. The interaction between use cases and actors in this game are shown in Figure 2. 


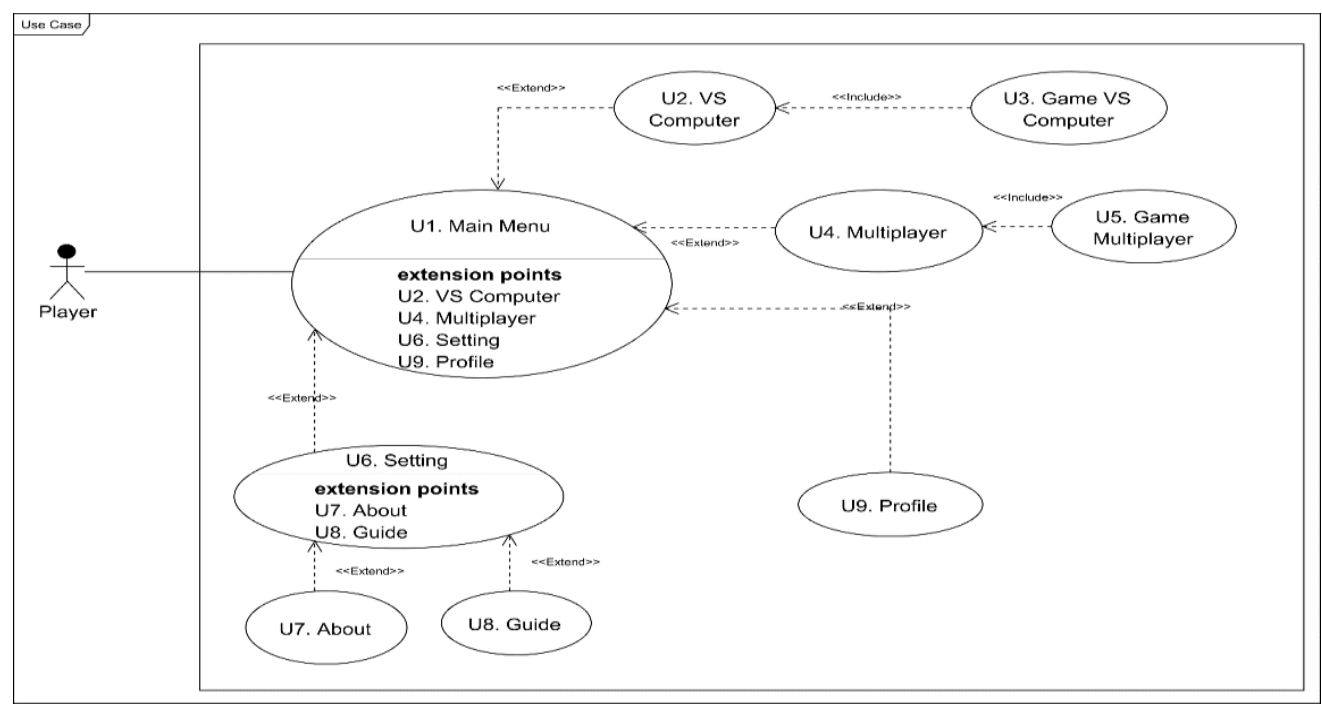

Fig. 2 Use Case Diagram

C. Class Diagram
There are 11 (eleven) class in this game. The relationship of each class that is described using inheritance and generalization as shown in Figure 3.

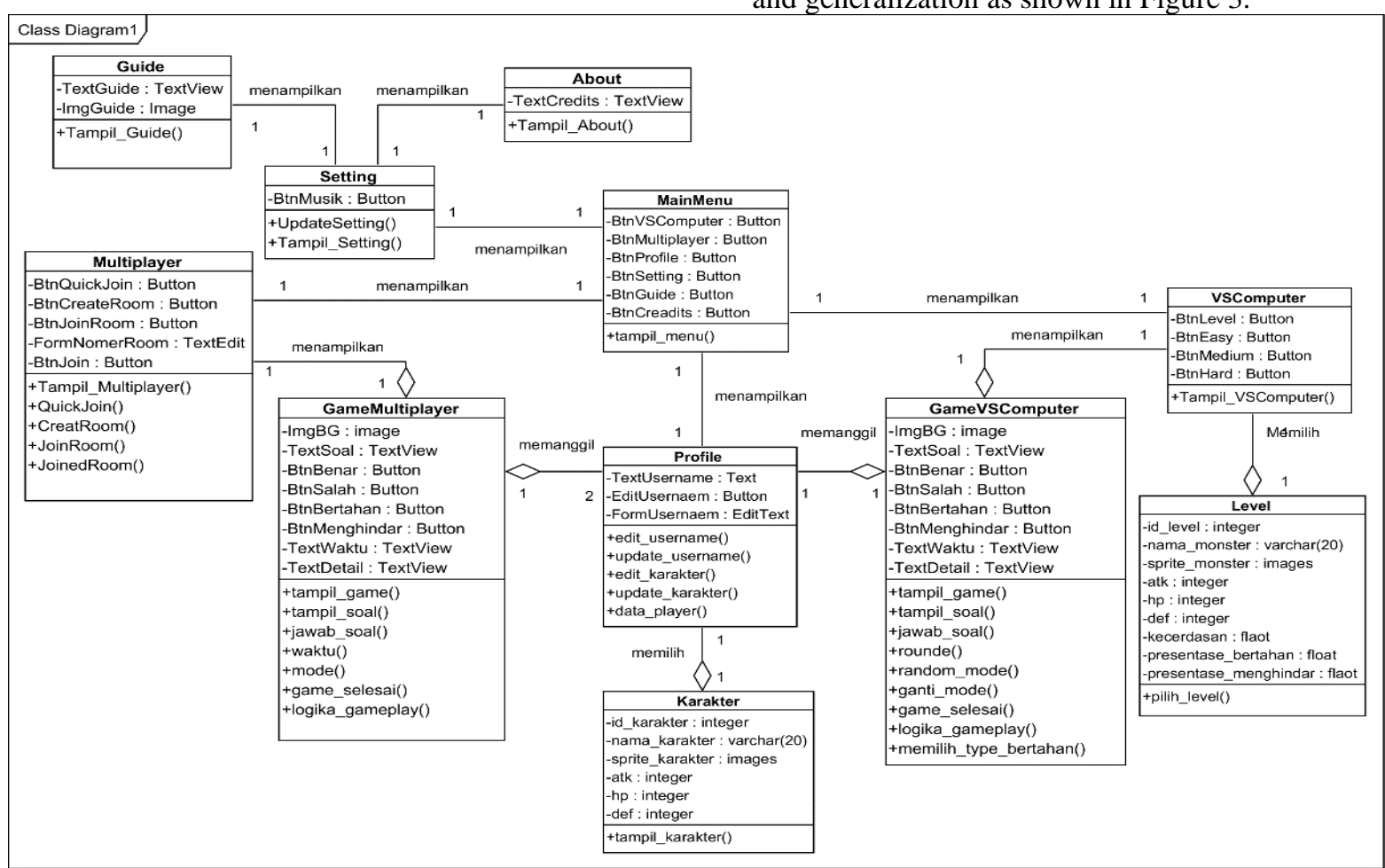

Fig. 3. Class Diagram

\section{IMPLEMENTATION}

Results interface exist in the game turn based strategy for sharpening knowledge of Indonesian culture based on Android, the interface main menu, VS computers, game VS the computer (type survive), Game VS computer
(Problem), the interface Multiplayer, Multiplayer Join Room , Multiplayer (waiting), Multiplayer Games (attack), setting, about, guide, and profile.

The results of some of the game's user interface shown in Figure 4 and Figure 5. 


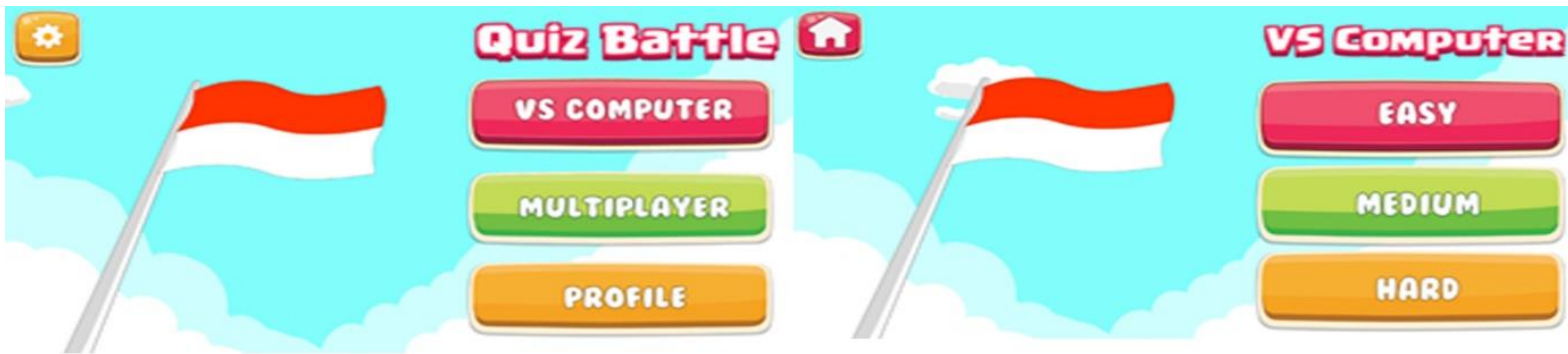

a) Antarmuka Main Menu berisi menu-menu dalam game

b) Antarmuka VS Computer berisi 3 tombol (easy, medium, hard)

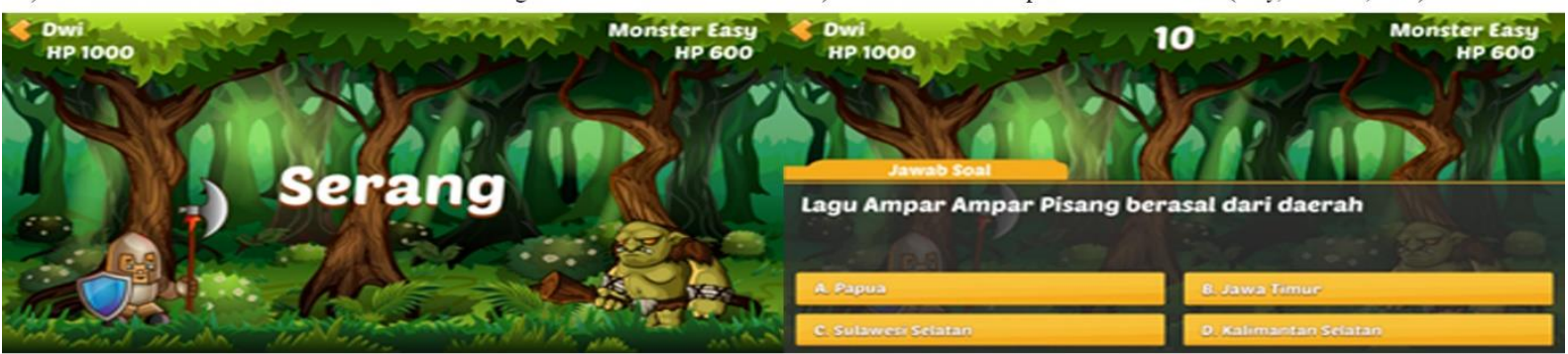

c) Antarmuka Game VS Computer saat user sedang bertarung dengan monster

d) Antarmuka pertarungan menampilkan soal dalam game

Figure 4 Results Vs Computer Interface

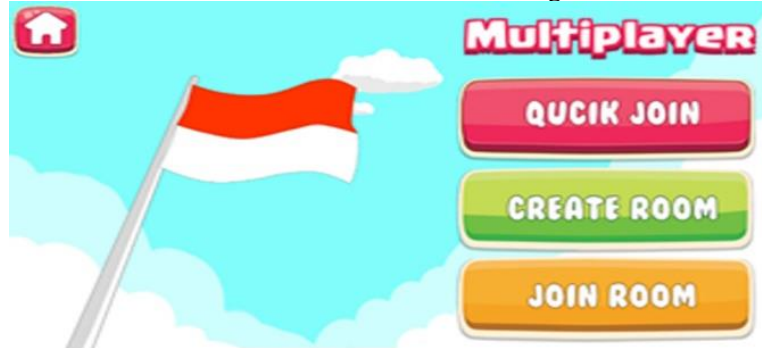

a) Antarmuka implementasi dalam game untuk tampilan Multiplayer

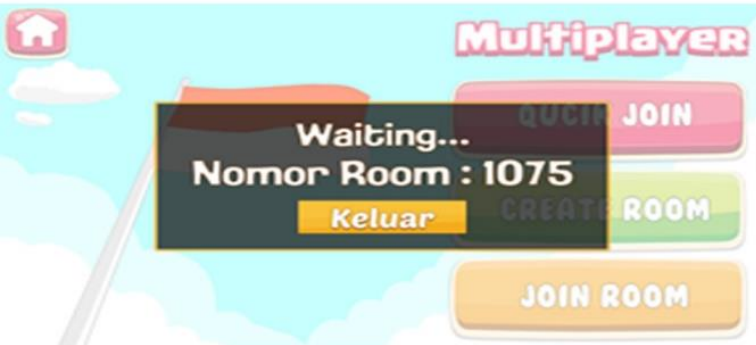

c) Antarmuka Multiplayer setelah create room

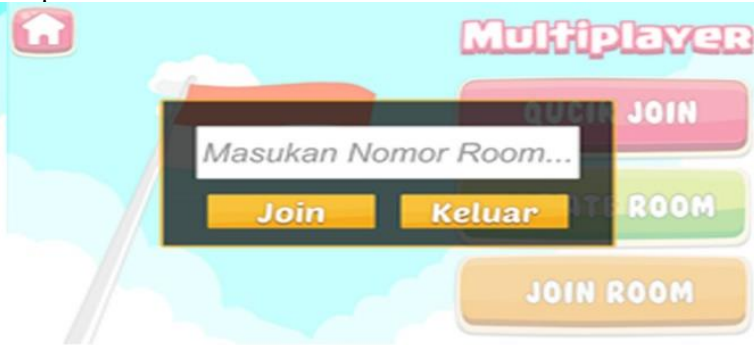

b) Antarmuka multiplayer untuk bergabung dengan room yang sudah dibuat

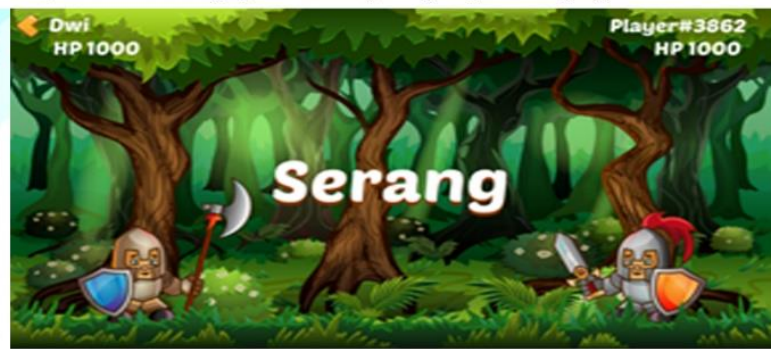

d) Antarmuka pertarungan multiplayer dalam game

Fig. 5. Results Interface Multiplayer

\section{CONCLUSION}

Turn based strategy game developed using the Unity Engine and minimal operating in Android platform 4.1 (jelly bean). This game genre of strategy games and educational, and is played by 1 (one) or 2 (two) users, who in the play there will be some questions that will arise in the form of questions of knowledge about the culture of Indonesia to be able to continue to the next stage.

As for the problems that exist in this game is about the traditional houses, traditional weapons, traditional dance, traditional songs, and cultural heritage of Indonesia.

\section{REFERENCES}

[1] C. R. Semiawan, Belajar dan Pembelajaran Prasekolah dan Sekolah Dasar. Jakarta: PT. Index, 2008.

[2] W. Pratama, "Game Adventure Misteri Kotak Pandora," ejournal.amikpurwokerto.ac.id, 2014

[3] S. Poespowardojo, Pembangunan Nasional Dalam Perspektif Budaya. Jakarta: Grasindo, 1993.

[4] A. L. Sanjaya, G. S. Budhi, and Liliana, "Pembuatan Turn Based Strategy Role Playing Game Menggunakan Unity Game
Engine," INFRA, 2015

[5] E. Handriyantini, "Permainan Edukatif Berbasis Komputer Untuk Siswa Sekolah Dasar, Sekolah Tinggi Informasi \& komputer. Malang," 2009.

[6] I. Binanto, Multimedia Digital - Dasar Teori dan Pengembangannya. Yogyakarta: ANDI, 2010.

[7] Wahana Komputer, Tip \& Trik Adobe Photoshop CS6. Semarang: ANDI, 2014

[8] M. Fowler, UML DISTILLED, Edisi 3. Yogyakarta: ANDI, 2005. 